\section{Förderungspreis 2018 der Schweizerischen Gesellschaft für Phlebologie}

Die Schweizerische Gesellschaft für Phlebologie (SGP-SSP) vergibt jährlich einen Förderungspreis im Betrag von SFr. 10'000.- Dadurch soll die wissenschaftliche Forschung, die technologische Entwicklung und die klinische Bildung auf dem Gebiet der Phlebologie im weitesten Sinne unterstützt werden. Berücksichtigt werden Arbeiten und Projekte, welche sich in einem fortgeschrittenen Stadium befinden und innerhalb eines Jahres abgeschlossen werden können. Ein Protokoll darf im gleichen Jahr nur an eine, der in den Gesellschaften der „Union Schweizerischer Gesellschaften für Gefäßkrankheiten" ausgeschriebenen Preisausschreiben, eingereicht werden.

Bewerber richten ein ausführliches Gesuch an die Präsidentin der Schweizerischen Gesellschaft für Phlebologie, Prof. Dr. Christina Jeanneret, Med. Universitätsklinik, Angiologie, KSBL, CH-4101 Bruderholz (E-Mail: christina.jeanneret@ksbl.ch).

Das Protokoll soll per Mail gesendet werden (PDF-Format) und detaillierte Angaben über die Verwendung der Preissumme enthalten. Die Begutachtung des Gesuches erfolgt durch den Vorstand der Schweizerischen Gesellschaft für Phlebologie. Die publikationsreife Arbeit muss den Vermerk „ausgezeichnet mit dem Förderungspreis der Schweizerischen Gesellschaft für Phlebologie“ aufweisen. Die Resultate sind im Rahmen einer Veranstaltung der SGP vorzustellen.

Eingabetermin: 30. September 2018

Benachrichtigung des Preisträgers: Ende Dezember 2018

\section{Prix de la Société Suisse de Phlébologie 2018}

La Société Suisse de Phlébologie (SSP-SGP) attribue chaque année un prix scientifique d'un montant de SFr. 10'000.-, dont le but est d'encourager la recherche scientifique, le développement technologique et la formation clinique en phlébologie. Seront pris en considération des travaux et des projets scientifiques déjà suffisamment avancés pour pouvoir être terminés dans le délai d'une année. Un protocole ne peut être soumis quà une seule des sociétés de l' „Union des Sociétés Suisse des Maladies Vasculaires" dans l’année courante.

Les candidats au prix adresseront une demande détaillée par email (PDF) à la présidente de la Société Suisse de Phlébologie, Prof. Dr. Christina Jeanneret, Med. Universitätsklinik, Angiologie, KSBL, CH-4101 Bruderholz

(Email: christina.jeanneret@ksbl.ch).

Ce rapport définira de façon détaillée, la manière dont le candidat envisage d'utiliser le montant du prix. La demande sera examinée par le comité de la Société Suisse de Phlébologie. Le travail, lors de sa publication, mentionnera qu'il a été „honoré du Prix de la Société Suisse de Phlébologie“. Les résultats de cette recherche devront être présentés au cours d'une réunion officielle de la Société Suisse de Phlébologie.

Délai d'inscription: 30 septembre 2018

Avis au lauréat du Prix: fin décembre 2018

\section{Award 2018 of the Swiss Society of Phlebology}

The Swiss Society of Phlebology (SSP-SGP) provides an annual Scientific Award of SFr 10 '000.-. It's aim is to promote scientific research, technical development and clinical skill in phlebology. Only advanced research and projects capable of being finished within a year delay may be considered. A protocol may only be submitted to one society at a time in the "Union of Vascular Societies of Switzerland" in the same year.

Candidates for this award should submit a detailed request per email (pdf file) to the president of the Swiss Society of Phlebology, Prof. Dr. Christina Jeanneret, Med. Universitätsklinik, Angiology, KSBL, CH-4101 Bruderholz, Switzerland

(E-mail: christina.jeanneret@ksbl.ch).

This request should precisely define the utilization of the amount of the Award and will be examined by the Board of the Swiss Society of Phlebology. Publication of any results would have to mention that they were supported by the „Award of the Swiss Society of Phlebology" and the results would also be presented in one of its official sessions.

Submission deadline: September 30th, 2018

Announcement of the winner: end of December 2018

Verantwortlich für Mitteilungen der SGP:

Prof. Dr. Christina Jeanneret-Gris,

Bruderholz www.phlebology.ch

Schweizerische Gesellschaft für Phlebologie

Société Suisse de Phlébologie 